\title{
PENINGKATAN EKSPRESI TRANSFORMING GROWTH FACTOR BETA 1 (TGF ß1) PADA LUKA DIABETES MELITUS MELALUI BALUTAN MODERN
}

\author{
Heri Kristianto $^{1,2^{*}}$, Elly Nurachmah ${ }^{3}$, Dewi Gayatri ${ }^{3}$ \\ 1. Program Studi Ilmu Keperawatan Fakultas Kedokteran Universitas Brawijaya, Jawa Tengah, Indonesia \\ 2. Program Studi Magister Fakultas Ilmu Keperawatan Universitas Indonesia, Depok 16424, Indonesia \\ 3. Fakultas Ilmu Keperawatan Universitas Indonesia, Depok 16424, Indonesia \\ *Email: herik26@yahoo.com
}

\begin{abstract}
Abstrak
Ekspresi transforming growth factor beta 1 pada luka diabetes melitus mengalami penurunan yang berdampak terhadap proses penyembuhan luka. Penelitian ini bertujuan untuk membandingkan perawatan luka modern dressing dengan metode konvensional terhadap ekspresi transforming growth factor beta 1 pada luka kaki diabetes melitus. Penelitian menggunakan quasi experimental pretest-posttest design dengan metode pengumpulan sampel secara consecutive sampling. Pengukuran ekspresi transforming growth factor beta 1 dilakukan pada hari ke-0 (pretest) dan ke-4 (posttest). Hasil penelitian didapatkan data pada kelompok modern terjadi peningkatan ekspresi transforming growth factor beta 1, sedangkan pada kelompok konvensional terjadi penurunan ekspresi transforming growth factor beta 1. Disimpulkan bahwa teknik perawatan luka secara modern mampu meningkatkan ekspresi transforming growth factor beta ldibandingkan teknik konvensional pada luka kaki diabetes melitus.
\end{abstract}

Kata kunci: konvensional, luka diabetes melitus, modern, transforming growth factor beta 1

\begin{abstract}
Reduction of expression of transforming growth factor beta 1 in diabetic ulcers affects overall wound healing. This study tried to draw a comparison of transforming growth factor beta 1 level between modern dressing and conventional dressing in diabetic foot ulcer. This study applied a quasi-experimental pretest-posttest design and a consecutive sampling method of data collection. Immunohistochemical analysis of transforming growth factor beta 1 level was measured on the day 0 (pretest) and the day 4 (posttest). In this study, the modern dressing application improves transforming growth factor beta 1 level. Meanwhile, the conventional dressing application decreases transforming growth factor beta 1 level. Thus, it can be concluded that the modern dressing application can increase transforming growth factor beta 1 level.
\end{abstract}

Key words: conventional, diabetic ulcer, modern, transforming growth factor beta 1

\section{Pendahuluan}

Diabetes melitus dapat menimbulkan dampak luas bagi kualitas hidup pasien, terutama dengan komplikasi luka kaki diabetik. Perkembangan penyakit diabetes melitus (DM) di seluruh dunia saat ini berkembang pesat, didukung dengan angka kejadian DM di dunia mencapai 171 juta jiwa pada 2000 dan diperkirakan akan mencapai 366 juta jiwa pada 2030 (Wild, et al., 2004).

Data dari Departemen Kesehatan RI (2007), prevalensi DM secara nasional 5,7\%. Di Indonesia jumlah penderita DM tahun 2000 mencapai 8,4 juta dan diprediksi oleh WHO tahun 2030 akan menjadi 21,3 juta jiwa (Perkeni, 2006).

Data dari WHO menunjukkan, kebanyakan penderita DM di negara berkembang usia 45-64 tahun (Perkeni, 2009). Ulkus dan ganggrein diabetik merupakan komplikasi pada ekstremitas bawah yang dapat berakhir amputasi.

Hasil penelitian NLLIC (2008) menyebutkan 67\% dari semua tindakan amputasi disebabkan DM, sedangkan Perkeni (2009) menyebutkan 30-50\% pasien paska amputasi akan dilakukan tindakan amputasi pada sisi kaki lain dalam waktu 1-3 tahun.

Data Perkeni (2009), angka kematian karena ulkus dan gangrein mencapai 17-23\% dan 15-30\% karena tindakan amputasi. Angka kematian satu tahun paska amputasi berkisar 14,8\% dan meningkat pada tiga tahun paska amputasi $37 \%$ dengan rerata umur pasien hanya 23,8 bulan paska amputasi. Karakteristik ulkus dan gangrein diabetik dilihat dari perubahan faktor pertumbuhan yaitu terjadinya penurunan TGF $\beta 1$ (Jude, et al., 2002). 
Menurut Genna (2003), menyebutkan bahwa salah satu faktor yang menghambat penyembuhan luka diabetes adalah kurangnya faktor pertumbuhan. TGF- 31 berperan dalam proses pembentukan kapiler baru sebagai saluran penyuplai oksigen dan makanan yang dibutuhkan oleh luka selama proses regenerasi jaringan.

Metode perawatan yang tepat diharapkan meningkatkan produksi TGF $ß 1$ sehingga memperpendek masa rawat luka. Penelitian terkait kecepatan penyembuhan luka pada teknik modern dan konvensional telah banyak dilakukan penelitian, tetapi pengaruhnya terhadap TGF $\beta 1$ masih belum banyak dilakukan kajian lebih lanjut.

\section{Metode}

Penelitian ini menggunakan quasi experimental design, dilakukan pengamatan pretest dan posttest control group design, selama empat hari (Wood \& Haber, 2006). Pengukuran TGF $\beta 1$ pada hari ke-0 untuk mengetahui jumlah TGF $\beta 1$ pada kondisi sebelum dilakukan pengamatan yang menjadi acuan perkembangan yang terjadi setelah diberikan tindakan rawat luka. Pada hari ke-4 dilakukan pengukuran kembali TGF $\beta 1$ sehingga didapatkan adanya trend perubahan produksi TGF $\beta 1$.

Adanya trend perubahan jumlah TGF $\beta 1$ selama empat hari pengamatan akan dijadikan acuan dalam pengolahan analisis data. Populasi penelitian yaitu pasien dengan luka diabetik yang dilakukan perawatan di rumah sakit wilayah Malang dan Madiun, yang baru maupun lama menjalani proses perawatan, dengan sampel pasien dengan luka diabetik yang menjalani perawatan pada PebruariApril 2010. Sampel diambil dengan cara consecutive sampling, dengan 30 responden.

Kriteria inklusi dalam penelitian ini adalah, 1) pasien bersedia menjadi sampel penelitian, 2) pasien dapat membaca dan menulis, 3) pasien dalam kondisi pengendalian kadar gula darah, 4) ditemukan jaringan nekrotik pada luka kaki DM (klasisifkasi Wagner: 4-5). Sedangkan, kriteria eksklusi dalam penelitian ini adalah, 1) menderita anemia dan hipoalbumin, 2) mendapatkan terapi NSAIDs dan anti neoplasma, 3) penyakit penyerta; gagal ginjal, stroke, kanker, aterosklerosis, dan gangguan daya ingat.
Analisis imunohistokimia (IHK) dilakukan di laboratorium Histologi dan Faal divisi Fisiologi Molekuler Fakultas Kedokteran Universitas Brawijaya. Tempat pemotongan jaringan nekrotik dilakukan di ruangan perawatan rumah sakit dimana pasien dilakukan tindakan rawat luka, baik prosedur pretest dan posttest. Hasil pemotretan IHK dianalisis dengan program Corel Photo Paint 12 untuk melihat derajat warna kecoklatan terhadap ekspresi TGF $\beta 1$. Analisis data statistik menggunakan uji T. Uji homogenitas karakteristik sampel menggunakan uji $T$ independent dan Chi square. Data diuji pada tingkat kemaknaan 5\% atau selang kepercayaan $95 \%$.

\section{Hasil}

\section{Karakteristik Sampel}

Rerata usia pasien DM dalam penelitian ini adalah 55,72 tahun pada kelompok modern dan konvensional (standar deviasi=7,52). Usia paling muda 44,4 tahun dan usia paling tua 73 tahun. Hasil estimasi interval menunjukkan $95 \%$ usia pasien DM dalam penelitian pada rentang 53,77-57,66 tahun.

Rerata lama hari rawat pasien DM dalam penelitian adalah 1,17 hari pada kelompok modern dan konvensional (standar deviasi= 1,13 hari). Lama hari rawat terendah 0 hari dan tertinggi empat hari. Hasil estimasi interval menunjukkan 95\% lama hari rawat pasien DM dalam penelitian pada rentang 0,87-1,46 hari.

Tabel 1. Rerata Perbedaan Ekspresi TGF $\beta 1$ Sebelum dan Setelah Pengamatan Pada Kelompok Modern dan Konvensional

\begin{tabular}{llllccc}
\hline Variabel & Kelompok & & & SD & t & p \\
\hline Ekspresi & Modern & Pretest & 148,31 & 10,56 & $-3,98$ & $0,000^{*}$ \\
TGF $\beta 1$ & & Posttest & 162,21 & 15,14 & & \\
\cline { 2 - 7 } & Konvensional & Pretest & 159,12 & 10,68 & 5,20 & $0,000^{*}$ \\
& & Posttest & 148,05 & 7,13 & & \\
\hline
\end{tabular}

*bermakna pada $\alpha=0,05$

Sebagian besar pasien DM dengan IMT normal, yaitu $56,7 \%$ kelompok modern dan konvensional. Pasien dengan luka DM dengan 10\% IMT kurang dan 33,3\% IMT lebih pada kelompok modern dan konvensional. Pasien DM 61,7\% berjenis kelamin perempuan dan 38,3\% laki-laki pada kelompok modern dan konvensional. 
Hasil analisis data karakteristik riwayat merokok menunjukkan 68,3\% tidak merokok dan 31,7\% mempunyai riwayat merokok pada kelompok modern dan konvensional.

Hasil uji homogenitas sampel menunjukkan terdapat kesamaan atau tidak berbeda secara signifikan pada karakteristik usia $(\mathrm{p}=0,687, \alpha=0,05)$, lama hari rawat $(\mathrm{p}=0,175, \alpha=0,05)$, IMT $(\mathrm{p}=0,101, \alpha=$ $0,05)$, danjenis kelamin $(p=0,288, \alpha=0,05)$. Sedangkan riwayat merokok $(p=1,00, \alpha=0,05)$ antara kelompok modern dan konvensional.

Hasil pengukuran ekspresi TGF $\beta 1$ pada hari ke-0 terdapat perbedaan yang signifikan $(\mathrm{p}=0,00, \alpha=$ $0,05)$. Perbedaan pada pretest (hari ke-0) tidak berpengaruh terhadap analisis perubahan ekspresi TGF $\beta 1$ karena yang dilihat ialah trend perubahannya.

\section{Rerata Perbedaan Ekspresi Transforming Growth Factor Beta 1 Sebelum dan Setelah Pengamatan Pada Kelompok Modern dan Konvensional}

Hasil analisis data menunjukkan rerata ekspresi TGF $\beta 1148,31$ pada kelompok modern hari ke-0 (pretest) (standar deviasi $=10,56$ ) dan setelah hari ke-4 (posttest) terjadi peningkatan menjadi 162,21 (standar deviasi=15,14). Ekspresi TGF $\beta 1$ 159,12 pada kelompok konvensional hari ke-0 (pretest) (standar deviasi $=10,68$ ) dan setelah hari ke-4 (posttest) terjadi penurunan menjadi 148,05 (standar deviasi=7,13).

Hasil analisis menunjukkan terdapat perbedaan ekspresi TGF $\beta 1$ yang signifikan antara pengukuran hari ke- 0 (pretest) dengan hari ke-4 (posttest) pada kelompok konvensional dan modern $(\mathrm{p}=0,00, \alpha=$ $0,05)$.

Tabel 2. Rerata Perbedaan Ekspresi TGF $\beta 1$ Setelah Pengamatan Pada Kelompok Modern dan Konvensional

\begin{tabular}{clcccc}
\hline Variabel & Kelompok & Mean & SD & t & p \\
\hline Ekspresi TGF $\beta 1$ & Modern & 162,21 & 15,14 & 4,633 & $0,000^{*}$ \\
& Konvensional & 148,05 & 7,13 & & \\
\hline
\end{tabular}

*bermakna pada $\alpha=0,05$

Pada kelompok modern terjadi peningkatan ekspresi TGF $\beta 1(13,89)$ sedangkan pada kelompok konvensional terjadi penurunan ekspresi TGF $\beta 1$ $(11,07)$. Rerata perbedaan ekspresi TGF $\beta 1$ sebelum dan setelah pengamatan tersaji dalam tabel 1 .

\section{Rerata Perbedaan Ekspresi Transforming Growth Factor $\beta 1$ Setelah Pengamatan Pada Kelompok Modern dan Konvensional}

Hasil analisis data menunjukkan rerata ekspresi TGF $\beta 1$ 162,21 pada kelompok modern hari ke-4 (posttest) (standar deviasi=15,14). Ekspresi TGF $\beta 1$ 148,05 pada kelompok konvensional hari ke-4 (posttest) (standar deviasi=7,13). Hasil analisis data selanjutnya menunjukkan terdapat perbedaan ekspresi TGF $\beta 1$ yang signifikan antara kelompok konvensional dan modern pada hari ke-4 (posttest) $(p=0,00, \alpha=0,05)$. Rerata perbedaan ekspresi TGF $\beta 1$ setelah pengamatan tersaji dalam tabel 2 .

\section{Rerata Perubahan Ekspresi Transforming Growth Factor $\beta 1$ setelah Pengamatan Pada Kelompok Modern dan Konvensional}

Hasil analisis data menunjukkan bahwa rerata perubahan ekspresi TGF $\beta 1$ 13,89 pada kelompok modern selama empat hari pengamatan (standar deviasi=19,10). Perubahan bersifat positif artinya terjadi peningkatan ekspresi TGF $\beta 1$. Perubahan ekspresi TGF $\beta 1$ 11,07 pada kelompok konvensional selama empat hari pengamatan (standar deviasi $=11,64)$. Perubahan bersifat negatif artinya terjadi penurunan ekspresi TGF $\beta 1$. Hasil analisis data selanjutnya menunjukkan terdapat perbedaan perubahan ekspresi TGF $\beta 1$ yang signifikan antara kelompok modern dan konvensional selama empat hari pengamatan $(p=0,00, \alpha=0,05)$. Gambaran perubahan derajat warna kecoklatan pada ekspresi TGF $\beta 1$ tersaji pada gambar 1 dan tabel 3 .

\section{Pembahasan}

Perubahan ekspresi TGF $\beta 1$ disebabkan adanya perlakuan perawatan luka secara modern dan konvensional. Faktor lain seperti usia, IMT, lama hari rawat, jenis kelamin, dan riwayat merokok tidak berpengaruh dalam penelitian. Hal ini didukung adanya kehomogenan karakteristik sampel antara kedua kelompok berdasarkan uji statistik.

Mekanisme kerja utama teknik balutan modern yaitu menjaga kelembapan pada luka (Dealey, 2005). 


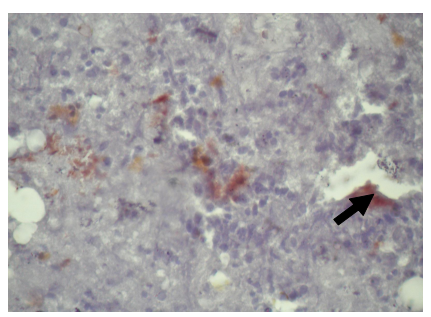

(a)

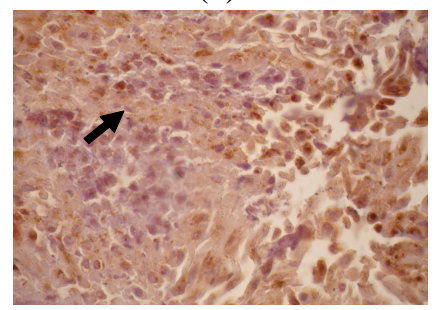

(d)

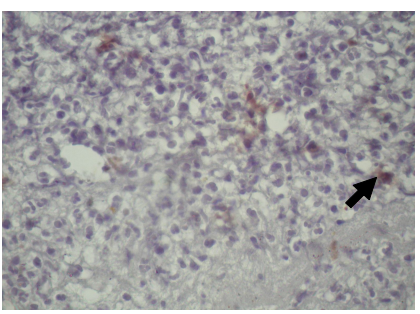

(b)

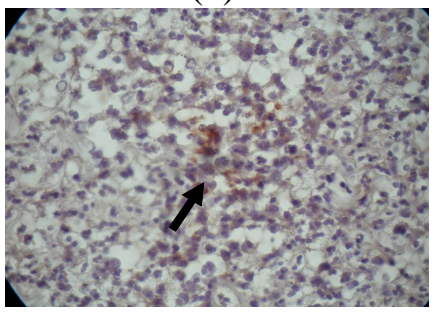

(e)

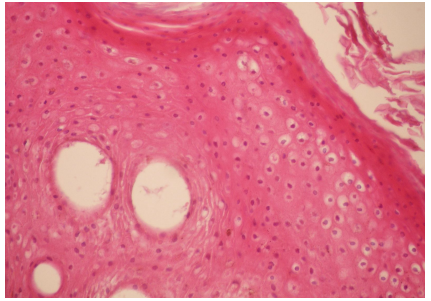

(c)

\section{Keterangan:}

(a) Modern hari ke-0

(b) Konvensional hari ke-0

(c) Tanpa IHK/ Pewarna HE sebagai pembanding

(d) Modern hari ke-4

(e) Konvensional hari ke-4

Gambar 1. Ekspresi TGF ß1 Pada Kelompok Modern dan Konvensional

Mekanisme kondisi lembab membantu proses penyembuhan luka melalui jalur fibrinolisis, angiogenesis, pembentukan growth factor, dan stimulasi sel aktif. Ketika terjadi proses penghancuran fibrin akan dipengaruhi oleh produksi platelet, sel endotel, dan fibroblas yang mekanismenya sangat dipengaruhi kondisi lembab (Bryan, 2004).

Kondisi ulkus kaki diabetik yang telah terjadi proses inflamasi memanjang akan berdampak pada terlambatnya pertumbuhan jaringan baru. Secara fisiologis, fase awal inflamasi ini sebenarnya tubuh telah memproduksi salah satu faktor pertumbuhan, yaitu TGF 31 yang berkontribusi terhadap proliferasi jaringan. Adanya mekanisme kelembapan pada balutan modern akan membantu peningkatan produksi platelet, monosit, dan fibroblas sehingga meningkatkan sintesis TGF $\beta 1$.

Mekanisme molekuler terjadinya pembentukan TGF ß1 berlangsung secara positif terhadap jumlah platelet, monosit, dan fibroblas, artinya jika suatu jaringan mengalami kerusakan maka akan diproduksi secara besar-besaran platelet, monosit dan fibroblas. Kemudian sinyal tersebut dilanjutkan terhadap TGF $ß 1$ untuk mengambil sel-sel inflamasi sehingga diproduksi berlebihan TGF 31 (Faler, et al., 2006).

Hasil penelitian Collo dan Pepper (1999) menyebutkan TGF 31 bekerja secara sendiri dan/ atau bersama-sama dengan faktor pertumbuhan lain dalam menginduksi ekspresi integrin $\alpha 5 \beta 1$ yang sangat diperlukan bagi proses migrasi sel endotel selama proses angiogenesis. TGF $ß 1$ dapat bekerja sebagai kemoatraktan bagi fibroblas dan stimulasi proliferasi terutama pada ECM yang berperan dalam proses pembentukan jaringan granulasi baru, migrasi sel keratinosit, dan meningkatkan kontraksi luka (Mauviel, 2009).

Hasil pengamatan secara makroskopis saat perawatan hari ke-0 dibanding hari ke-4 pada kelompok modern ditemukan kondisi luka tidak berbau, minimal eksudat. Produksi eksudat minimal dan tidak berbau merupakan salah satu aplikasi konteks kenyamanan lingkungan menurut Kolcaba karena dapat mempengaruhi respon lingkungan sekitarnya (Kolcaba, 2008).

Proses pertumbuhan jaringan baru pada balutan modern terjadi lebih cepat. Hal ini berarti mekanisme kerja balutan modern yang bersifat lembab sangat membantu mekanisme pembentukan dan kerja dari TGF 1. Pengamatan selama penelitian, pada balutan konvensional yang menggunakan iodin, $\mathrm{H}_{2} \mathrm{O}_{2}$, metronidasol, dan kompres kassa dengan $\mathrm{NaCl}$ $0,9 \%$, bersifat melekat dengan dasar luka, minimal menyerap eksudat, frekuensi penggantian balutan lebih sering, dan proses perubahan warna dasar luka menjadi merah sangat lambat.

Proses perlekatan antara kasa dengan dasar luka dapat menyebabkan terjadinya cedera ulang terhadap gelung-gelung kapiler yang akan dan baru terbentuk sehingga proses angiogenesis yang akan lebih lama dan menimbulkan resiko infeksi sebagai dampak melekatnya serabut-serabut kassa pada dasar luka sebagai media pertumbuhan mikrobakteri. 
Tabel 3. Rerata Perbedaan Perubahan Ekspresi TGF $\beta 1$ Setelah Pengamatan Pada Kelompok Modern dan Konvensional

\begin{tabular}{cccccc}
\hline Variabel & Kelompok & Mean & SD & t & p \\
\hline Ekspresi TGF $\beta$ 1 Modern & 13,89 & 19,10 & 6,11 & $0,000^{*}$ \\
Konvensional & $-11,07$ & 11,64 & & \\
\hline
\end{tabular}

*bermakna pada $\alpha=0,05$

Pada akhirnya sel mengalami penurunan untuk memproduksi TGF $\beta 1$ sehingga akan terjadi penurunan ekspresi TGF $\beta 1$ (Jude, et al., 2002). Apabila terjadi dalam waktu lama, hal ini dapat memperlama fase inflamasi sehingga luka menjadi kronik serta sulit untuk berproliferasi (Agren \& Werthen, 2007).

Pada balutan modern berbeda, meskipun ada proses penempelan balutan pada dasar luka tetapi bersifat lembab sehingga mudah dilepaskan dari dasar luka. Pada beberapa jenis balutan serabut tersebut akan berubah menjadi gel, jika terkena cairan luka sehingga tetap mempertahankan kelembapan luka dan mampu mengikat bakteri serta mencegah terjadi perdarahan berlebihan. Ketika dilakukan pencucian luka pada balutan modern, serabut tersebut akan rontok dari dasar luka dengan membawa debrisdebris dan jaringan mati.

Jaringan nekrotik pada teknik konvensional lebih luas, mengeras dan berbau terutama slough yang disebabkan mekanisme autolitik debridemen lebih lambat terjadi karena kondisi luka kurang lembab dan kering. Kondisi ini memicu mikroorganisme untuk tumbuh dan berkembang pada jaringan mati karena miskin oksigen (anaerob).

Pada akhirnya berdampak pada proses regenerasi jaringan karena proses produksi TGF $\beta 1$ sebagai faktor stimulasi terjadi penghambatan angiogenesis. Kemampuan kasa dalam menyerap eksudat sangat terbatas berdampak terhadap seringnya balutan dibuka untuk meminimalkan bau. Hal ini meningkatnya resiko cedera ulang pada dasar luka akibat manipulasi dasar luka saat penggantian balutan.

Pemakaian iodine $1 \%$ dan $\mathrm{H}_{2} \mathrm{O}_{2}$ dalam proses perawatan luka merupakan salah satu hal yang dapat memicu rusaknya gelung-gelung kapiler yang terbentuk (Selim, 2002). Pemakaian iodine dan $\mathrm{H}_{2} \mathrm{O}_{2}$ hanya dibatasi pada luka kotor setelah trauma dan terinfeksi yang dapat menurunkan terjadinya infeksi serta tidak menggunakan teknik rendam/ siram serta dipakai dalam jangka pendek saja (The Joanna Briggs Institute, 2006).

Saat masa perawatan pada luka kronik, menghindari pemakaian cairan iodine dan $\mathrm{H}_{2} \mathrm{O}_{2}$ sehingga luka beregenerasi sempurna dan direkomendasikan menggunakan normal salin 0,9\%. Penggunaan antiseptik menyebabkan sitotoksik pada sel sehingga proses pembentukan TGF $\beta 1$ terganggu serta merusak calon fibroblas dan kolagen yang akan terbentuk. Hasil penelitian dari Khan \& Naqvi (2006) menunjukkan iodine bersifat menginduksi Tumor Nekrosis Faktor $\alpha(\mathrm{TNF} \alpha)$ dan menginhibisi produksi interleukin-6 (IL-6) dari makrofag, menghambat growth factor yang penting dalam menginduksi proses inflamasi.

Teknik perawatan luka secara konvensional yang menggunakan metronidasol tabur bertujuan menurunkan infeksi dan mengurangi bau luka. Metronidasol bekerja melawan bakteri anaerobik dan mempengaruhi periode inflamasi.

Hasil penelitian Sampaio, et al. (2009) menyebutkan metronidasol mampu menstimulasi produksi kolagen dan angiogenesis, tetapi pengaruh terhadap TGF $\beta 1$ masih belum jelas. Penggunaan metronidasol berdampak terhadap peningkatan resistensi bakteri sehingga perlu dihindari pemakaian berlebih (Brazier, Stubbs, Duerden, 1999).

\section{Kesimpulan}

Hasil penelitian disimpulkan rerata responden mempunyai karakteristik usia 55,72 tahun dan lama rawat inap 1,17 hari. Sebagian besar responden dengan IMT normal, berjenis kelamin perempuan dan tidak mempunyai riwayat merokok pada teknik modern dan konvensional.

Pada teknik modern terdapat peningkatan ekspresi TGF ß1, sedangkan teknik konvensional terdapat penurunan ekspresi, bermakna pada perawatan luka diabetes melitus sebelum dan setelah pengamatan. Hasil akhir disimpulkan terdapat perbedaan ekspresi TGF $\beta 1$ yang bermakna pada perawatan luka diabetes melitus setelah pengamatan antara teknik modern dan konvensional. 
Peneliti merekomendasikan pengkajian ulang SOP tindakan rawat luka dimasing-masing rumah sakit terkait dengan metode perawatan luka yang digunakan sehingga akan memperbaiki sistem layanan asuhan keperawatan sehingga akan bermanfaat bagi penderita luka kaki DM khususnya. Bentuk perbaikan tersebut yaitu, durasi penggantian balutan, jenis balutan, kebijakan standar alat kesehatan pada perawatan luka, peningkatan kemampuan, dan pengetahuan perawat khusus luka, terutama pemakaian balutan jenis modern. Peneliti menganjurkan perlu dilakukan kajian lebih lanjut aplikasi teori kenyamanan dari Kolcaba terhadap perubahan mikroseluler (TG, RS, TN).

\section{Referensi}

Agren, M. S., \& Werthen, M. (2007). The extracellular matrix in wound healing: A closer look at therapeutics for chronic wounds. International Journal of Low Extrem Wounds. Diperoleh dari http://ijl.sagepub.com/cgi/content/ abstract/6/2/82.

American Diabetes Association. (2005). Oral agents for type 2 diabetes: An update. Diperoleh dari www.diabetesjournals.org.

Brazier, J. S., Stubbs, S. L. J., \& Duerden, B. I. (1999). Metronidazole resistance among clinical isolates belonging to the Bacteroides fragilis group: Time to be concerned? Journal Antimicrob Chemother. Diperoleh dari http://jac.ox fordjournals.org/cgi/content/full/44/4/580.

Bryan, J. (2004). Moist wound healing: A concept that changed our practice, Journal of Wound Care. Diperoleh dari http:// www. woundconsultant.com/files/ Moist_Wound_Healing2.pdf.

Collo, G., \& Pepper, M. S. (1999). Endhotelial cell integrin a $5 \beta 1$ expression is modulated by cytokines and during migration in vitro, Journal Cell Science. Diperoleh dari www.sagepub.com.

Dealey, C. (2005). The care of wounds: A guide for nurses. Victoria: Blackwell Publishing.

Faler, B. J., Macsata, R. A., \& Plummer, D. (2006). Focus on basic science: Transforming growth factor- $\beta$ and wound healing. Sage Publication. Diperoleh dari http://pvs.sagepub.com.

Genna, J. G. (2003). Neuropathic foot ulcers. Dalam Milne, C. T., Corbett, L. Q., \& Dubuc, D. L. (Eds.), Wound, ostomy, and continence nursing secrets (Hal. 175). Philadelphia: Hanley \& Belvus, Inc.
Jude, Blakytny, Bulmer, Boulton, \& Ferguson. (2002). Abstract: Transforming growth factor-beta 1, 2, 3 and receptor type I and II in diabetic foot ulcers. Journal of Diabetes UK. Doi: 10.1046/j.14645491. 2002.00692.x. Diperoleh dari http://www. blackwell synergy. com/.

Khan, M. N., \& Naqvi, A. H. (2005). Antiseptics, iodine, povidone iodine and traumatic wound cleansing. Tissue Viability Society. Diperoleh dari www.tvs.org.uk/sitedocument/Khan_16.pdf.

Kolcaba. (2008). The web site devoted to the concept of comfort in nursing. Diperoleh dari http://www.thecomfortline.com/index. htm.

Mauviel, A. (2009). Transforming growth factor- $\beta$ signaling in skin: Stromal to epithelial cross-talk, Journal of Investigative Dermatology. Diperoleh dari http://www.nature.com/jid/journal/ v129/n1/pdf/jid2008385a.pdf.

NLLIC. (2008). Diabetes and lower extremity amputations, Knoxville: Ampute Coalition of America (ACA). Diperoleh dari www.amputeecoalition.org/nllic_topic/06 08_bilateral_lowe r_extremity.html.

Perkeni. (2006). Konsensus pengelolaan dan pencegahan diabetes melitus tipe 2 di Indonesia. Diperoleh dari www.scribd.com.

Perkeni. (2009). Pedoman penatalaksanaan kaki diabetik. Jakarta: PB Perkeni.

Sampaio, C. P. P., Simoes, M. L. P. B, Trindade, L. C. T., Farias, R. E., Pierin, R. J., Martins, R. C. (2009). Inflammatory alterations provoked by metronidazole in wounds: an experimental study in rats. Jornal Vascular Brasileiro. Diperoleh dari www.scielo.br/scielo.php?pid=S 1677 script=sci_arttext.

Selim, P. (2002). Promoting evidence-based nursing practice - The use of antiseptics in wound management: A community nursing focus. RDNS. Diperoleh dari http://www. rdns.net.au.

The Joanna Briggs Institute. (2006). Solutions, techniques and pressure in wound cleansing. Best Practice. Blackwell Publishing. Diperoleh dari http://www.joannabriggs.edu.au/pdf/ BPISEng_10.pdf.

Wild, S., Roglic, G, Green, A., Sicree, R., \& King, H. (2004). Global prevalence of diabetes: Estimates for the year 2000 and projections for 2030, Diabetes Care, 27 (5). Diperoleh dari http:// www. who.int/diabetes/facts/en/ diabcare0504.pdf.

Wood, G.L., \& Haber, J. (2006). Nursing research. St. Louis: Mosby. 